\title{
LOCAL ECONOMIC DEVELOPMENT STRATEGIES TO INCREASE ECONOMIC GROWTH IN AGROTOURISM AREAS
}

\author{
Retno Sari Mahanania (iD), Taufik Hidayat ${ }^{\mathrm{b}}$ (D), Irma Wardatic (D), \\ Andarula Galushastid (D), Luluk Cahyo Wiyono (iD)
}

\footnotetext{
${ }^{a}$ Politeknik Negeri Jember, Department of Agribusiness Management; https://orcid.org/0000-0002-2721-9358; e-mail: retno7089@gmail.com

b Politeknik Negeri Jember, Department of Agribusiness Management; https://orcid.org/0000-0002-7117-2382; e-mail: taufik_hidayat@polije.ac.id

c Politeknik Negeri Jember, Department of Agriculture Production; https://orcid.org/0000-0002-6453-9246; e-mail: irmawardati@gmail.com

d Politeknik Negeri Jember, Department of Agribusiness Management; https://orcid.org/0000-0002-4268-8363; e-mail: andarula.galushasti@gmail.com

e Politeknik Negeri Jember, Department of Agribusiness Management; http://orcid.org/0000-0002-7684-8492; e-mail: luluk_cahyo_wiyono@polije.ac.id
}

How to cite (APA style): Mahanani, R.S., Hidayat, T., Wardati, I., Galushasti, A., Wiyono, L.C. (2021). Local economic development strategies to increase economic growth in agrotourism areas. Turyzm/Tourism, 31 (2), 117-131. https://doi.org/10.18778/0867-5856.31.2.07

\begin{abstract}
This study aims to find a local economic development strategy based on agroindustry to increase Java's agrotourism sustainable and robust local economy. The research methods used are descriptive quantitative and qualitative. Research respondents are the community, academic practitioners and government officials. The data used covers both external and internal factors that affect the local economy in an agrotourism area and which are then analyzed using SWOT. The results show that the main strength of agrotourism in the IFE matrix is its highly strategic geographical location. The weakness is the lack of planning and business development activity which could have potential economic value. In the EFE matrix, opportunities are the prospects for agrotourism development while the main threat is the community's low interest in business development. In the IE matrix, agrotourism development is found in cell V. This can be handled by maintaining strategies such as market penetration, and market and product development. The study concludes that the local economic development of the community in the agrotourism area can be implemented if the community, practitioners and government are integrated to support the strategy.
\end{abstract}

\section{KEYWORDS}

development strategy, economic strategy, community economy, agroindustry strategy, agrotourism area

\section{ARTICLE INFORMATION DETAILS}

Received:

4 September 2021

Accepted:

2 November 2021

Published:

21 December 2021

\section{INTRODUCTION}

The implementation of regional autonomy has challenges for regions (regencies/cities) to develop their capability to mobilize and manage the production, allocation and distribution of various resources into superior products with competitive advantages. Economic development is when the community manages existing resources and forms a partnership to create new jobs and stimulate economic growth. The idea 
of local economic development (LED) is to explore and develop the regional potential and so to improve agricultural areas based on local resources. This LED approach provides opportunities for the community to play a role and take the initiative in determining and processing those resources, both human and natural. It was taken up because humans are part of nature, and natural conditions are seen as a suitable place to relax from the daily routine. One kind of tourism, following the idea of back to nature, that can be developed in Indonesia is agrotourism. These tourism businesses by utilizing the potential of agriculture for recreational purposes, raise knowledge and develop business relationships with agriculture (Djuwendah, Karyani, Wulandari, 2021).

West Java is a province with many attractive natural tourist sites making it a top destination for domestic and international tourists. One area in West Java that offers a variety of agrotourism is the tourist area of South Bandung. Visitors can enjoy nature's beauty and participate in the community's daily activities to learn about agriculture, art and culture, and enjoy traditional culinary delights. The tourist attractions offered include agricultural education, outdoor activities, cultural interactions, culinary tourism (education specialties) and homestays (Djuwendah, Karyani, Wulandari, 2021).

Banyuroto Village, Magelang is a strawberry development center in Central Java, located in the Merabu valley, with an elevation of about 1,300 m above sea level. The climate makes the location particularly suitable for developing sub-tropical horticulture such as strawberries of which several cultivars are developed for agrotourism programs. Development is being carried out in order to improve the quality of strawberry production that presently continues to decline. It also helps to improve the standard of living of the natives there (Hakim, Widyorini, Nugroho, Prayitno, 2021).

Jember Regency, East Java, has a rural agricultural feel that holds much natural wealth. In addition, from a social and economic perspective, the majority of the population are farmers. Their condition is suitable to support village planning as an agrotourism area, thus increasing value and income for villagers and districts. Research is needed on LED strategies to create solid and sustainable economic growth and establish sustainable agrotourism sites in the Jember Regency (Mahanani, Wiyono, Hidayat, Sugiartono, Pratiwi, 2020).

This study investigates several internal and external factors that can affect LED and finds appropriate strategies to be applied by the community, practitioners and government using strategic planning methods.

\section{LITERATURE REVIEW}

\subsection{StRATEGY MANAGEMENT}

The word strategy has many meanings, and all of them suggest something helpful, important and relevant for organizations and companies. A strategy is a plan of action that allows each organization member to understand the reasons for the organization's existence and how specific targets can be achieved (Athapaththu, 2016). Strategic planning is a critical mechanism for integrating, coordinating, centralizing and decentralizing organizational decision-making. Strategic planning plays an essential role in formulating critical problems, setting goals, analyzing alternatives and selecting strategies for organizations (Wolf, Floyd, 2013). Strategic management involves understanding an organization's strategic position, strategic choices for the future and managing strategy in action (Omalaja, Eruola, 2011). Strategy research uses several conceptual lenses: a cost view, a resource-based view, organizational learning, agency theory and financial concepts related to organizations (Ferreira, dos Reis, Pinto, 2016). A good understanding of the concept of strategy will determine the success of one to be drawn up. According to Rangkuti (1997), strategic concepts give distinctive competence and competitive advantage.

Distinctive competence is action taken by the company to perform activities better than its competitors (Rangkuti, 1997) and should be superior to the competencies of other companies and be difficult to imitate (Mooney, 2007). Thus, distinctive competencies help a company stand out in its market (Mooney, 2007). Competitive advantage is another specific activity developed by a company to be superior to its competitors (Rangkuti, 1997). Competitive advantage can be a company's capabilities, superior resources, such as a favorable location, a desirable product or a recognizable brand name, that enable the company to be successful (Mooney, 2007). Business strategy is one that focuses on improving the competitive position of a company's products/services or specific market segments and overcomes the problem of how the company and its units can compete in business and industry with the help of internal-external metrics (Wheelen, Hunger, 2012). Business strategy focuses on a particular business area, studying how to improve competitiveness by selecting a more attractive market segment and identifying the right approach to establish a favorable competitive position (Lin, Hsing, Wang, 2008).

The commercialization of agriculture is limited to cash crops and is functional in developing and expanding agricultural activities (Noviar et al., 2020). Innovations and strategies for developing regional assets will shift 
the economy's pattern from agriculture to services, one of which is tourism (Nuryasman, Nuringsih, Cokki, 2020) with agrotourism often being referred to as a promising diversification strategy (Vogt, 2013). The success of the Agriwosata project depends on tourism taking place and adapting to ongoing village activities along with implementing other non-tourism forms of rural development (Pal, 2016).

\subsection{LOCAL ECONOMIC DEVELOPMENT (LED)}

Every regional economic development effort aims to increase the number and types of job opportunities for the community. To improve regional development, especially in developing areas, local governments seek to improve the community's welfare by exploring and developing the potential that exists in the region. LED is a process that encourages partners from the community as well as public, private and non-governmental sectors, to carry out collective work and create favorable conditions for economic growth so as to create jobs to improve the local economy's future and the quality of life for all citizens (Mandisvika, 2015). The main goal of regional development is to increase labor productivity and the skills and competence of workers. They can improve a company's strategic capabilities, its position in national and international markets, increase corporate activity, knowledge diffusion, innovation orientation, complementary relationships with other companies, employment, and make better use of existing resources (Garofoli, 2020). LED plays an essential role in creating jobs, eradicating poverty and improving the quality of life (Meyer, 2014). It offers local governments, communities and the private sector an opportunity to work together to improve the local economy by innovation based on local potential. The LED approach will succeed if society improves the investment and business climate that enables increased competitiveness, jobs and income (World Bank, 2011) According to Swinburn et al. (2006), the determinants of LED are demographic (including human resources and human capital), the local economy and business environment, infrastructure, regional and national policies, opportunities and competitors. Classification of LED determinants can be carried out in six dimensions: demographics, economic structure, income, essential services, spatial location and governance (Simms, Freshwater, Ward, 2014). Agrotourism is essential for LED, especially for marginalized rural areas with environmental and cultural heritage (Shah Shah, Shah, 2020). Agrotourism is recognized as an alternative economic activity among farmers due to its ability to generate on-site and off-site income for themselves and related communities (Saxena, Clark,
Oliver, Ilbery, 2007). Recreational opportunities in rural areas can generate income and employment for local communities.

\subsection{SWOT ANALYSIS OF AGROTOURISM BUSINESS}

LED strategies are formulated by identifying internal and external factors that affect LED activities. They are combined using a SWOT analysis which compares them with the local economic conditions desired. A SWOT strategic planning model is a method for strategy selection and decision making for an organization, for cooperation, for a particular geographic area or for an issue or problem to improve efficiency (Mustika, Khrisna Aditya, 2018). SWOT analysis is used to investigate the strengths and weaknesses of rural tourism alongside environmental opportunities and risks. Given the integrated rural development model, in addition to modern agriculture, it also encourages the development of complementary activities such as the production and sale of agricultural products through rural tourism activities (Krasavac-Chroneos, Radosavljević, Bradić-Martinović, 2018). Appropriate solutions and strategies to achieve tourism and rural development are presented through a SWOT analysis so as to optimize and effectively utilize strengths and opportunities, while eliminating weaknesses and threats (Majid, Hajari, Karimian, Hajiloo, 2013). It is not only beneficial for developed tourism destinations however, it is also helpful for agrarian villages where tourism activities are not present but with potential for agrotourism development, so proper development strategies are needed (Bhatta, Ohe, Ciani, 2020). Each SWOT analysis represents Strengths, Weaknesses, Opportunities and Threats. Overall, it can be divided into two parts: the first is SW, mainly used to analyze internal conditions; the second is OT, mainly used for analyzing external conditions (Zhang, 2012). With this method, favorable and worthwhile factors to be promoted from agribusiness-based LED in the agrotourism area of Java can be found and harmful things avoided. Through this method, problems will be found but solutions will be too, and future development clarified.

\section{RESEARCH METHOD}

The research methods used in this research are descriptive quantitative and qualitative approaches. This research aims to uncover contemporary sociological and social science phenomena concerning various tourism issues spread throughout Java. Data collection 
techniques include surveys, interviews, observation and documentation. The data used in this study cover both external and internal factors that can affect a community's economy in an agrotourism area and were obtained from 2019 to 2020. Research respondents are communities, practitioners and relevant government agencies. In this case, the prospective respondents are individuals or government agencies living in the vicinity of agrotourism. The data is then processed and analyzed using SWOT to formulate a strategy. The stages of data analysis are as follows:

1. Internal Factor Evaluation (IFE) Matrix

This matrix aims to see the strengths and weaknesses of a business (internal factors). A rating score of 1-4 is made for each internal factor with the following conditions: major weakness (1), minor weakness (2), low strength (3), and high strength (4). The rating value is based on a company's internal organisation and is industry-based.

2. External Factor Evaluation (EFE) Matrix

This matrix aims to see the opportunities and threats to a business (external factors). A rating value of 1-4 is made for each external factor indicating how effective the company's current strategy is in responding to these factors, creating a rating value based on a company's internal organisation and is industry-based.

3. Internal External (IE) Matrix

The IE (Internal External) matrix positions the various divisions of an organization into nine cells. Divisions that fall into cells I, II or IV can be described as growing. Intensive strategies (market penetration, market and product development) or integration (backward, forward and horizontal) would be most appropriate for these divisions. Divisions that fall into cells III, V or VII can be handled through guarding and defending strategies; market penetration and product development are the two most used here. Divisions that fall into cells VI, VIII or IX are 'harvesting' or 'divesting'.

4. SWOT Matrix

SWOT matrix is an important matching tool that helps companies develop four types of strategy, SO (strength of opportunity), WO (weakness of opportunity), ST (strength of threat), and WT (weakness of threat). The steps in forming a SWOT Matrix are to list a company's:

- key external opportunities,

- main external threats,

- primary internal strengths,

- primary internal weaknesses.

To match internal

- strengths with external opportunities, recording the results in an SO strategy;

- weaknesses with external opportunities, recording the results in a WO strategy;
- strengths with external threats, recording the results in an ST strategy;

- weaknesses with external threats, recording the results in a WT strategy.

\section{RESULTS}

\subsection{IFE MATRIX}

The IFE matrix is prepared based on interviews with several relevant government agencies, academic practitioners and residents. The weighting is done by comparing each of the internal agrotourism factors to find the priorities. Furthermore, the rating is done by looking at actual conditions of agrotourism potential to find the main strengths and weaknesses in the agrotourism development area.

The development of agrotourism has strengths and weaknesses that are above the average standard of 2.50 . Table 1 shows that its main strength is a highly strategic geographical location with a score of 0.533 .

Table 1. IFE Matrix

\begin{tabular}{|c|c|c|c|c|}
\hline No & Internal Factors & Value & Rating & Score \\
\hline \multicolumn{5}{|c|}{ Strengths } \\
\hline 1 & $\begin{array}{c}\text { Highly strategic } \\
\text { geographical location }\end{array}$ & 0.133 & 4 & 0.533 \\
\hline 2 & Appropriate workforce & 0.087 & 4 & 0.346 \\
\hline 3 & Age & 0.095 & 3 & 0.286 \\
\hline 4 & Level of education & 0.080 & 3 & 0.240 \\
\hline 5 & Perseverance / Motivation & 0.115 & 4 & 0.462 \\
\hline 6 & Broad marketing aspects & 0.124 & 4 & 0.497 \\
\hline \multicolumn{5}{|c|}{ Weaknesses } \\
\hline 7 & $\begin{array}{l}\text { There is no adequate } \\
\text { information system } \\
\text { in public services }\end{array}$ & 0.061 & 2 & 0.122 \\
\hline 8 & $\begin{array}{l}\text { Government support that } \\
\text { is not well-directed }\end{array}$ & 0.064 & 2 & 0.129 \\
\hline 9 & Lack of local labor absorption & 0.051 & 2 & 0.102 \\
\hline 10 & $\begin{array}{l}\text { Lack of planning } \\
\text { and business development } \\
\text { actions that have potential } \\
\text { economic value }\end{array}$ & 0.132 & 1 & 0.132 \\
\hline 11 & Poor waste management & 0.056 & 2 & 0.113 \\
\hline & 1.000 & - & 2.962 \\
\hline
\end{tabular}

Source: authors.

\subsection{EFE MATRIX}

The EFE matrix is prepared based on interviews conducted with several relevant government agencies, academic practitioners and residents. The weighting is 
done by comparing each of the external factors to find the priorities. The rating is done by comparing the potential response for agrotourism development to the opportunities and threats that exist or will be faced.

Table 2 shows that the main opportunity factor for agrotourism development is its prospect for the future with a score of 0.836 . Meanwhile, the main threat is the low interest of the public in business development with a score of 0.206 . Local associations, including farmers as agrotourism stakeholders, are significant in the participatory planning process for generating appropriate support across various interests (Wanner, Pröbstl-Haider, Feilhammer, 2021). The total score for the external factors combined is 2.853. In dealing with opportunities and threats, this can be seen as good because it has exceeded the average standard at 2.50.

Table 2. EFE Matrix

\begin{tabular}{|c|c|c|c|c|}
\hline No & External Factors & Value & Rating & Score \\
\hline \multicolumn{5}{|c|}{ Opportunities } \\
\hline 1 & $\begin{array}{c}\text { Prospects for agrotourism } \\
\text { development }\end{array}$ & 0.209 & 4 & 0.836 \\
\hline 2 & Supporting natural resources & 0.101 & 4 & 0.404 \\
\hline 3 & Rich in superior products & 0.094 & 3 & 0.282 \\
\hline 4 & $\begin{array}{c}\text { There is still a vast market } \\
\text { opportunity }\end{array}$ & 0.129 & 4 & 0.516 \\
\hline 5 & Create a farmers' group & 0.086 & 3 & 0.259 \\
\hline \multicolumn{5}{|c|}{ Threats } \\
\hline 6 & $\begin{array}{c}\text { Low public interest } \\
\text { in business development }\end{array}$ & 0.206 & 1 & 0.206 \\
\hline 7 & $\begin{array}{c}\text { Society stigma about } \\
\text { the importance of education }\end{array}$ & 0.054 & 2 & 0.109 \\
\hline 8 & $\begin{array}{c}\text { Many unemployed } \\
\text { at working age }\end{array}$ & 0.059 & 2 & 0.118 \\
\hline 9 & $\begin{array}{c}\text { Garbage and waste have } \\
\text { not been managed properly }\end{array}$ & 0.061 & 2 & 0.123 \\
\hline \multicolumn{5}{|c|}{} \\
\hline
\end{tabular}

Source: authors.

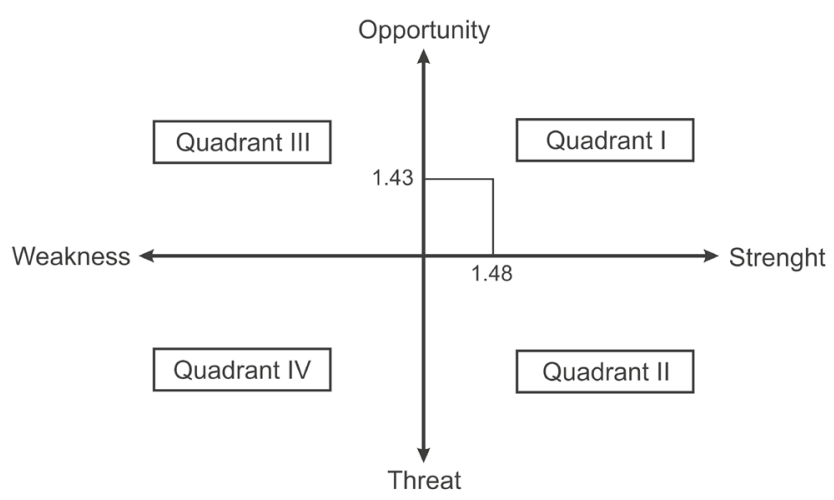

Figure 1. SWOT Matrix Source: authors
Tables 1 and 2 can determine the matrix of critical strategies for developing a local agribusiness/ agroindustry-based economy. In this case, it is to develop agrotourism in the Java regencies through the swot analysis quadrant. The IFE value (1.48) represents the value on the $\mathrm{x}$-axis, and the EFE value (1.43) represents the value on the y-axis (Figure 1). From Figure 1, it is known that the development of agrotourism lies in quadrant 1 . This shows that the development of agrotourism has valuable strengths and opportunities.

\subsection{IE MATRIX}

The total weighting result of the IFE matrix is 2.962, and for the EFE matrix, 2.853. These results are mapped onto the IE matrix where the $x$-axis is the total value of the IFE matrix, and the y-axis is the total value of the EFE matrix. Thus, the IE matrix is obtained (Figure 2).

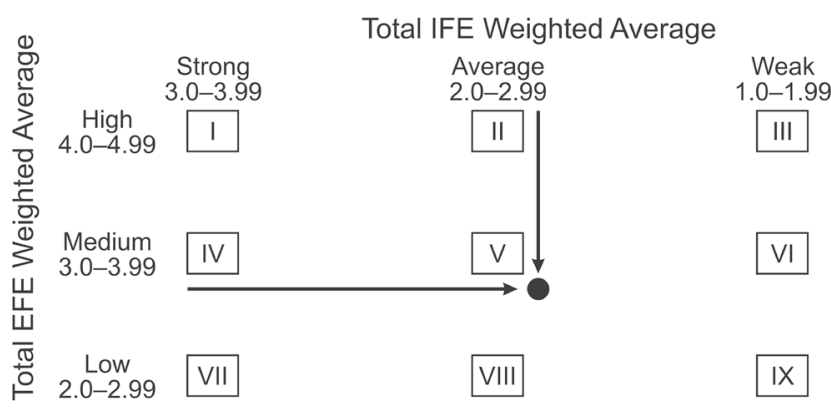

Figure 2. IE Matrix Source: authors

Figure 2 shows that agrotourism development is in cell V. Divisions included in cell V can be appropriately handled through a maintaining strategy.

\subsection{SWOT MATRIX}

A synthetic comparison of the results of past analyses is presented in the SWOT matrix (Table 3, see p. 122). It facilitates the choice of one of the four possible strategies of action.

\section{DISCUSSION}

From Table 1, the main disadvantage of agrotourism development is the lack of planning and business development with potential economic value having a score of 0.132 , so that the total integration score for internal factors is 2.962. The determinants of agrotourism development are geography, locality and 
Table 3. SWOT Matrix Analysis Results

\begin{tabular}{|c|c|c|c|}
\hline & \multicolumn{2}{|r|}{ Internal } \\
\hline & & Strength (S) & Weaknesses (W) \\
\hline & & $\begin{array}{l}\text { - Highly strategic geographical } \\
\text { location } \\
\text { - Appropriate workforce } \\
\text { - Age } \\
\text { - Level of education } \\
\text { - Perseverance/motivation } \\
\text { - Broad marketing aspects }\end{array}$ & $\begin{array}{l}\text { - There is no adequate information system } \\
\text { in public services } \\
\text { - Government support that is not well-directed } \\
\text { - Lack of local labor absorption } \\
\text { - Lack of planning and business development actions } \\
\text { that have potential economic value }\end{array}$ \\
\hline \multirow{4}{*}{ 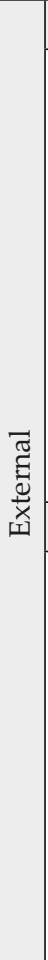 } & Opportunity (O) & SO Strategies & WO Strategies \\
\hline & $\begin{array}{l}\text { - Prospects for } \\
\text { agrotourism } \\
\text { development } \\
\text { - Supporting natural } \\
\text { resources } \\
\text { - Rich in superior products } \\
\text { - There is still a vast } \\
\text { market opportunity } \\
\text { - Create a farmers' group }\end{array}$ & $\begin{array}{l}\text { - Providing attractive tour packages } \\
\text { (S1, S2, S6 \& O1, O2, O4) } \\
\text { - Collaborating with residents } \\
\text { in providing lodging facilities to } \\
\text { receive more tourists and lengthen } \\
\text { stays (S2, S5, S6 \& O3, O5) } \\
\text { - Creating development innovations } \\
\text { based on research, skills } \\
\text { and experience to increase } \\
\text { the attractiveness of agrotourism } \\
\text { (S4, S5, S6 \& O1, O4) }\end{array}$ & $\begin{array}{l}\text { - Improving information system technology and the } \\
\text { use of social media for promotion to achieve more } \\
\text { comprehensive agrotourism development } \\
\text { (W1 \& O1, O4) } \\
\text { - Working together to open areas owned by residents } \\
\text { as additional tourism locations and become } \\
\text { a separate income for farmers' groups (W2, W3 } \\
\text { \& O2, O5) } \\
\text { - Optimizing the role of tour guides by residents } \\
\text { by providing informational services about nature } \\
\text { tourism along with existing superior products } \\
\text { (W1, W3 \& O2, O3) }\end{array}$ \\
\hline & Threats $(\mathrm{T})$ & ST Strategies & WT Strategies \\
\hline & $\begin{array}{l}\text { - Low public interest in } \\
\text { business development } \\
\text { - Society stigma about the } \\
\text { importance of education } \\
\text { - Many unemployed at } \\
\text { working age } \\
\text { - Garbage and waste have } \\
\text { not been managed } \\
\text { properly }\end{array}$ & $\begin{array}{l}\text { - Providing positive motivation } \\
\text { about the importance of education } \\
\text { and its level to overcome } \\
\text { unemployment at working age } \\
\text { and increase interest in business } \\
\text { development with additional } \\
\text { insights gained (S3, S4, S5, S6 } \\
\text { \& T1, T2, T3) } \\
\text { - Improving skills so that waste that } \\
\text { has economic value can be utilized } \\
\text { (S2, S3, S5 \& T4) }\end{array}$ & $\begin{array}{l}\text { - Integrating the government and the local } \\
\text { community regarding business planning } \\
\text { and development to maximize public services, } \\
\text { government support and assist in the absorption } \\
\text { of local workers } \\
\text { (W1, W2, W3, W4 \& T1, T3) } \\
\text { - The community helps in tackling environmental } \\
\text { pollution by transforming waste into goods } \\
\text { of economic value (W4, W5 \& T4) }\end{array}$ \\
\hline
\end{tabular}

Source: authors.

agrotourism space (Konečný, 2014). Figure 2 shows that agrotourism development can be handled through intensive strategies such as market penetration, and market and product development. Market penetration and product development are the two most widely used. Attracting customers who have not yet become regular but are occasional users by increasing brand loyalty can be a successful strategy for fast market growth (Murden, 2020).

This research shows that a highly strategic geographical location can be a major force in the development of agrotourism. Similarly, in other studies a major force in developing agrotourism is to conduct critical assessments on companies and take strategic steps that help them overcome most of the uncertainties they face (Eshun, Tettey, 2014). For the development of tourism in a village, as mentioned earlier, strength and opportunity are positive factors, while weakness and threat are negative factors (Bhatta, Ohe, Ciani, 2020). The development of regional or local agrotourism provides greater strength because understanding the region and the suitability of needs are more clearly seen (Košak, Lugomer, 2015).

The main opportunity is the prospects for agrotourism development. Meanwhile, the main threat is the low interest of the public in business development. In addition, this analysis agrees with several studies which suggest that in many communities the income collected benefits some village members only, a scenario that can develop into a dangerous apathy towards the development of agrotourism (Eshun, Tettey, 2014). Therefore, regional policymakers tend to focus on environmental efficiency to mitigate the negative effects of agrotourism development (such as improving energy facilities) (Belliggiano, Garcia, Labianca, Valverde, Rubertis, 2020). Almost all areas with outstanding and well-preserved cultural attributes now seek to involve local cultures and traditions into the development of agrotourism (Mardiany, Kusuma, Rayes, Hakim, 2021). Other opportunities 
are to provide access for tourists who like nature and rural environments while agrotourism allows them to experience agricultural activities (Tew, Barbieri, 2012). The environment for agrotourism development in a village is relatively favorable (Bhatta, Ohe, Ciani, 2020).

In addition, government agencies associated with tourism must take a proactive stance towards the development of agrotourism because a new institutional framework is needed to realize its potential for sustainable development (Eshun, Tettey, 2014). The development of agrotourism positively impacts tourists and local communities (Maneenetr, Naipinit, Tran, 2014) through the contribution of traditional knowledge thus increasing competitiveness and sustainability (Khanal, Shrestha, 2019; Mardiany, Kusuma, Rayes, Hakim, 2021).

Based on the analysis results, alternative strategies can be applied in economic agrotourism development efforts. These strategies can be to provide attractive tour packages, collaborate with locals in providing lodging facilities to receive more tourists and to lengthen stays, create development innovations based on research, skills and experience to increase the attractiveness of agrotourism. Issues to be challenged are the lack of an appropriate information system in public services, government support that is not well-directed, a lack of local labor absorption, a lack of planning and business development that could have potential economic value. Equally providing positive motivation about the importance of education and its levels, to address unemployment in those of working age and increasing interest in business development with additional insights, improving skills so that waste can be utilized for economic value, integrating government and local communities regarding business planning and development to maximize public services, government support and to assist in the absorption of local workers, and for communities to help address environmental pollution by transforming waste into goods of economic value.

\section{CONCLUSION}

This research concluded that it is essential to build integration between communities, practitioners and government institutions in supporting and building the potential of existing abundant resources. These resources can have a significant impact on the economic development of local agrotourism.

The findings here make a real contribution by showing that regional development strategies can provide opportunities for communities to play an active role and take the initiative in determining and processing local resources, both human and natural. The strategy can boost the regional economy, free the community from the limitations that hinder its efforts, and ensure the well-being of the unique environment.

\title{
LOKALNA STRATEGIA ROZWOJU UKIERUNKOWANA NA ZWIĘKSZENIE WZROSTU GOSPODARCZEGO NA OBSZARACH AGROTURYSTYCZNYCH
}

\author{
Retno Sari Mahanani ${ }^{\mathrm{a}}$ (D), Taufik Hidayat ${ }^{\mathrm{b}}$ (D), Irma Wardatic (D), \\ Andarula Galushastid (D), Luluk Cahyo Wiyono ${ }^{\mathrm{e}}$
}

\footnotetext{
a Państwowy Uniwersytet Politechniczny w Jemberze, Wydział Zarządzania Agrobiznesem; https://orcid.org/0000-0002-2721-9358; e-mail: retno7089@gmail.com

${ }^{b}$ Państwowy Uniwersytet Politechniczny w Jemberze, Wydział Zarządzania Agrobiznesem; https://orcid.org/0000-0002-7117-2382; e-mail: taufik_hidayat@polije.ac.id

c Państwowy Uniwersytet Politechniczny w Jemberze, Wydział Produkcji Rolnej; https://orcid.org/0000-0002-6453-9246; e-mail: irmawardati@gmail.com

d Państwowy Uniwersytet Politechniczny w Jemberze, Wydział Zarządzania Agrobiznesem; https://orcid.org/0000-0002-4268-8363; e-mail: andarula.galushasti@gmail.com

e Państwowy Uniwersytet Politechniczny w Jemberze, Wydział Zarządzania Agrobiznesem; http://orcid.org/0000-0002-7684-8492; e-mail: luluk_cahyo_wiyono@polije.ac.id
} 


\begin{abstract}
ABSTRAKT
Celem niniejszego opracowania jest określenie lokalnej strategii rozwoju gospodarczego opartej na rolnictwie, która pomogłaby w stworzeniu na Jawie zrównoważonej agroturystyki oraz prężnie działającej gospodarki lokalnej. Zastosowano w nim opisowe metody badawcze, zarówno ilościowe, jak i jakościowe. Osoby biorące udział w badaniu to członkowie lokalnej społeczności, naukowcy będący praktykami oraz urzędnicy państwowi. Omawiane dane odnoszą się zarówno do czynników zewnętrznych, jak i wewnętrznych, które mają wpływ na lokalną gospodarkę w sektorze agroturystyki. W celu ich zbadania wykorzystano analizę (macierz) SWOT. Otrzymane wyniki świadczą o tym, że najmocniejszą stroną agroturystyki w macierzy oceny czynników wewnętrznych (IFE Matrix) jest wysoce strategiczne położenie geograficzne, największą słabością zaś - brak planowania oraz przedsięwzięć ukierunkowanych na rozwój działalności, która potencjalnie ma ogromną wartość gospodarczą. W macierzy oceny czynników zewnętrznych (EFE Matrix) największą szansę stanowią możliwości rozwoju agroturystyki, a najpoważniejsze zagrożenie - niewielkie zainteresowanie lokalnej społeczności rozwojem biznesu. W macierzy oceny czynników wewnętrznych i zewnętrznych (IE Matrix) rozwój agroturystyki ulokowano w komórce V. Problemy z nim związane można rozwiązać dzięki stosowaniu takich strategii, jak penetracja rynku oraz rozwój rynku i produktu. Z opracowania płynie wniosek, że rozwój lokalnej gospodarki w obszarze agroturystyki w omawianej społeczności można osiągnąć, pod warunkiem że społeczność, praktycy i rząd podejmą współpracę w celu wsparcia wdrażanej strategii.
\end{abstract}

\section{SŁOWA KLUCZOWE}

strategia rozwoju, strategia gospodarcza, gospodarka wspólnotowa, strategie w przemyśle rolnym, agroturystyka

\section{INFORMACJE O ARTYKULE}

Przyjęto:

4 września $2021 \mathrm{r}$.

Zaakceptowano:

2 listopada $2021 \mathrm{r}$.

Opublikowano:

21 grudnia $2021 \mathrm{r}$.

\section{WSTĘP}

Wprowadzenie autonomii regionalnej dla poszczególnych jednostek administracyjnych (kabupatenów i kot) wiąże się z pewnymi wyzwaniami dotyczącymi rozwoju możliwości uruchomienia produkcji i zarządzania nią, alokacji i dystrybucji różnych zasobów w celu wytwarzania produktów wysokiej jakości, które miałyby przewagę konkurencyjną. O rozwoju gospodarczym można mówić wtedy, gdy społeczność potrafi właściwie zarządzać swoimi zasobami, nawiązywać współpracę, by tworzyć nowe miejsca pracy, oraz stymulować wzrost gospodarczy. Idea lokalnego rozwoju gospodarczego (LED) polega na zgłębianiu i rozwijaniu potencjału regionalnego, a co za tym idzie - na ulepszaniu obszarów rolniczych na podstawie lokalnych zasobów. Podejście LED otwiera przed społecznością możliwości odgrywania znaczącej roli i przejmowania inicjatywy $\mathrm{w}$ procesie ustalania oraz przetwarzania zasobów, zarówno ludzkich, jak i naturalnych. Zdecydowano się na nie, ponieważ ludzie są częścią natury, a obszary naturalne postrzega się jako miejsca odpowiednie do odpoczynku od codziennej rutyny. Jednym z możliwych do rozwijania na terenie Indonezji rodzajów turystyki ukierunkowanych na realizowanie idei powrotu do natury jest agroturystyka. Dzięki wykorzystaniu jej potencjału do celów rekreacyjnych przedsiębiorstwa turystyczne zwiększają świadomość oraz nawiązują relacje biznesowe z rolnictwem (Djuwendah, Karyani, Wulandari, 2021).
Jawa Wschodnia jest prowincją, w której znajduje się wiele atrakcyjnych naturalnych miejsc turystycznych, co czyni ją wiodącą destynacją nie tylko dla turystów krajowych, ale również zagranicznych. Jednym z obszarów Jawy Wschodniej obfitujących w rozmaite atrakcje agroturystyczne jest rejon Bandungu Południowego. Odwiedzający mogą się cieszyć pięknem natury, a także uczestniczyć w codziennych zajęciach tutejszej społeczności, by nauczyć się czegoś o rolnictwie, sztuce i kulturze regionu oraz spróbować lokalnych przysmaków. Do dostępnych atrakcji turystycznych można zaliczyć lekcje rolnictwa, zajęcia terenowe, interakcje kulturowe, turystykę kulinarną ( $\mathrm{w}$ tym naukę przyrządzania lokalnych specjałów) oraz zakwaterowanie u rodzin goszczących (Djuwendah, Karyani, Wulandari, 2021).

Wieś Banyuroto w pobliżu miasta Magelang stanowi centrum uprawy truskawek w Jawie Środkowej, usytuowane w dolinie Merabu, na wysokości ok. 1300 m n.p.m. Lokalny klimat sprawia, że jest to miejsce szczególnie sprzyjające rozwojowi sadownictwa subtropikalnego, w tym upraw truskawek, których kilka odmian dostosowano do potrzeb programów agroturystycznych. Odmiany opracowuje się w celu podniesienia jakości produkcji tych owoców, która obecnie cały czas spada. Przyczynia się to również do poprawy standardu życia miejscowej ludności (Hakim, Widyorini, Nugroho, Prayitno, 2021).

Kabupaten Jember w Jawie Wschodniej to obszar o wiejskim, rolniczym charakterze, obfitujący w dobra naturalne. Ponadto - ze społecznego i gospodarczego 
punktu widzenia - większość tamtejszej populacji stanowią rolnicy. Ich kondycja finansowa jest wystarczająco dobra, by mogli wspierać zagospodarowanie wsi jako obszaru agroturystycznego, co zapewne przełożyłoby się na zwiększenie wartości oraz wzrost dochodów mieszkańców wsi i poszczególnych kecamatanów ${ }^{1}$. Należy przeprowadzić badania nad strategiami LED w celu zapewnienia stałego i zrównoważonego rozwoju gospodarczego, jak również stworzenia zrównoważonych centrów agroturystycznych w kabupatenie Jember (Mahanani, Wiyono, Hidayat, Sugiartono, Pratiwi, 2020).

W niniejszym opracowaniu przeanalizowano poszczególne wewnętrzne i zewnętrzne czynniki, mogące mieć wpływ na lokalny rozwój gospodarczy. Omówiono także właściwe strategie, które powinny zostać wdrożone przez miejscową społeczność, praktyków oraz rząd przy wykorzystaniu metod planowania strategicznego.

\section{PRZEgLĄD Literatury}

\subsection{ZARZĄDZANIE STRATEGICZNE}

Słowo „strategia” ma wiele znaczeń, ale wszystkie sugerują coś przydatnego, ważnego oraz istotnego dla organizacji i firm. Strategia to plan działania, który pozwala każdemu członkowi danej organizacji zrozumieć powody jej istnienia oraz sposoby osiągnięcia wyznaczonych przez nią celów (Athapaththu, 2016). Planowanie strategiczne to mechanizm kluczowy dla integracji, koordynacji, centralizacji oraz decentralizacji podejmowania decyzji w organizacji. Odgrywa ono zasadniczą rolę $\mathrm{w}$ formułowaniu najistotniejszych problemów, wyznaczaniu celów, analizowaniu możliwości oraz wyborze strategii działania (Wolf, Floyd, 2013). Zarządzanie strategiczne obejmuje zrozumienie pozycji organizacji, wybory na przyszłość oraz zarządzanie strategią w praktyce (Omalaja, Eruola, 2011). W badaniu strategii wykorzystywanych jest kilka perspektyw pojęciowych, takich jak: perspektywa kosztów, szkoła zasobów kompetencji, organizacyjne uczenie się, teoria agencji oraz koncepcje finansowe związane $\mathrm{z}$ organizacją (Ferreira, dos Reis, Pinto, 2016). Od właściwego zrozumienia idei strategii zależy powodzenie tej, która zostanie obrana. Według Rangkutiego (1997) koncepcje strategiczne przekładają się na wybitne kompetencje oraz przewagę konkurencyjną.

Wybitne kompetencje to działania podejmowane tak, by wykonywać czynności lepiej niż konkurencja (Rangkuti, 1997). Powinny być one większe niż kompetencje innych firm oraz trudne do naśladowania (Mooney, 2007). Dlatego też wybitne kompetencje pomagają firmie wyróżnić się na rynku (Mooney, 2007).
Przewaga konkurencyjna to inne sprecyzowane działania opracowane przez firmę, by uzyskać przewagę nad konkurencją (Rangkuti, 1997). Mogą to być wydajność firmy i lepsze zasoby (np. sprzyjająca lokalizacja, pożądany produkt lub rozpoznawalna marka), umożliwiające firmie osiągnięcie sukcesu (Mooney, 2007).

Strategia biznesowa z kolei jest ukierunkowana na poprawienie pozycji konkurencyjnej produktów/ usług firmy lub konkretnych segmentów rynku, a także pomaga przezwyciężyć problem, jak firma lub jej oddziały mogą konkurować w biznesie za pomocą pomiarów wewnętrznych i zewnętrznych (Wheelen, Hunger, 2012).

Dzięki strategii biznesowej możliwe jest skupienie się na konkretnym obszarze działalności, przeanalizowanie, jak zwiększyć konkurencyjność poprzez wybór atrakcyjniejszego segmentu rynku, oraz zidentyfikowanie właściwego podejścia, które pomoże wypracować korzystną pozycję konkurencyjną (Lin, Hsing, Wang, 2008).

Komercjalizacja rolnictwa ogranicza się do upraw rynkowych i odgrywa ważną rolę w rozwijaniu oraz poszerzaniu zakresu związanych z nim działań (Noviar $i$ in., 2020). Innowacje oraz strategie rozwoju zasobów regionalnych powodują przekształcenie modelu gospodarczego z rolnictwa w usługi obejmujące turystykę (Nuryasman, Nuringsih, Cokki, 2020). Agroturystyka jest często wymieniana jako obiecująca strategia dywersyfikacji (Vogt, 2013). Sukces projektu Agrowisata zależy od tego, czy turystyka będzie prosperować, od przystosowywania się do podejmowanych na wsi działań, a także od wdrażania innych niż turystyka form rozwoju obszarów wiejskich (Pal, 2016).

\subsection{LOKALNY ROZWÓJ GOSPODARCZY (LED)}

Każdy wysiłek podejmowany w związku z regionalnym rozwojem gospodarczym ma na celu zwiększenie liczby i różnorodności ofert pracy dla członków lokalnej społeczności. Aby usprawnić rozwój regionalny, szczególnie na terenach rozwijających się, samorządy dążą do wzrostu dobrobytu lokalnej ludności poprzez badanie i zwiększanie potencjału obszaru. LED to proces, który zachęca partnerów z danej społeczności, jak również przedstawicieli sektora publicznego, prywatnego i pozarządowego do wykonywania pracy zbiorowej oraz stwarzania sprzyjających warunków do wzrostu gospodarczego, aby mogły powstawać miejsca pracy, które polepszą przyszłość lokalnej gospodarki oraz jakość życia wszystkich mieszkańców (Mandisvika, 2015). Głównym celem rozwoju regionalnego jest zwiększenie wydajności pracy, a także poszerzanie umiejętności i kompetencji pracowników, które mogą służyć polepszeniu zdolności strategicznych firmy, 
pozycjonowaniu na rynku krajowym oraz międzynarodowym, zwiększeniu aktywności przedsiębiorstw, rozpowszechnianiu wiedzy i zorientowaniu na innowacje, budowaniu komplementarnych relacji z innymi firmami, zatrudnieniu pracowników i zoptymalizowaniu wykorzystania posiadanych zasobów ludzkich (Garofoli, 2020). LED odgrywa kluczową rolę w tworzeniu miejsc pracy, zwalczaniu biedy i podnoszeniu jakości życia (Meyer, 2014). Stwarza samorządom, społecznościom i sektorowi prywatnemu okazję do współpracy w celu polepszenia lokalnej gospodarki poprzez wdrażanie innowacji opartych na miejscowym potencjale. Podejście LED będzie skuteczne wówczas, gdy społeczność poprawi klimat inwestycyjny i biznesowy, co z kolei umożliwi zwiększenie konkurencyjności, liczby miejsc pracy oraz dochodów (World Bank, 2011). Swinburn, Goga i Murphy (2006) twierdza, że czynniki warunkujące LED to: demografia (w tym zasoby ludzkie oraz kapitał ludzki), lokalna gospodarka oraz otoczenie biznesowe, infrastruktura, polityka regionalna i krajowa, możliwości oraz konkurencja. Klasyfikacji czynników LED można dokonać na sześciu płaszczyznach: demografii, struktury gospodarczej, dochodów, usług podstawowych, lokalizacji w przestrzeni oraz zarządzania (Simms, Freshwater, Ward, 2014).

Agroturystyka jest kluczowa dla rozwoju gospodarki lokalnej, szczególnie w przypadku marginalizowanych obszarów wiejskich, cechujących się bogatym dziedzictwem środowiskowym oraz kulturowym (Shah, Shah, Shah, 2020). Agroturystykę uznaje się za alternatywną działalność gospodarczą prowadzoną przez rolników, ze względu na jej zdolność generowania dochodu w gospodarstwie rolnym i poza nim, zarówno dla tych rolników, jak i dla powiązanej z nimi społeczności (Saxena, Clark, Oliver, Ilbery, 2007). Potencjał rekreacyjny obszarów wiejskich może generować dochody oraz szansę zatrudnienia dla przedstawicieli lokalnej społeczności.

\subsection{ANALIZA SWOT DLA BRANŻY AGROTURYSTYCZNEJ}

Strategie lokalnego rozwoju gospodarczego opracowuje się na podstawie zidentyfikowanych czynników wewnętrznych i zewnętrznych, wpływających na ten rozwój. Są one łączone za pomocą analizy SWOT, dzięki której można je porównać z pożądanymi lokalnymi warunkami gospodarczymi. Model planowania strategicznego SWOT jest metodą doboru strategii i podejmowania decyzji na poziomie organizacji, współpracy, konkretnego obszaru geograficznego lub problemu z poprawą wydajności (Mustika, Khrisna Aditya, 2018). Analizy SWOT używa się, aby zgłębić mocne i słabe strony turystyki na obszarach wiejskich w odniesieniu do szans i zagrożeń środowiskowych.
Model zintegrowanego rozwoju obszarów wiejskich poza nowoczesnym rolnictwem sprzyja także prowadzeniu działalności uzupełniającej, takiej jak wytwarzanie i sprzedaż płodów rolnych w ramach turystyki wiejskiej (Krasavac-Chroneos, Radosavljević, Bradić-Martinović, 2018).

Właściwe rozwiązania i strategie umożliwiające rozwój turystyki oraz obszarów wiejskich zostały zaprezentowane poprzez analizę SWOT, aby zoptymalizować i skutecznie wykorzystać mocne strony oraz szanse, przy jednoczesnej eliminacji słabych stron i zagrożeń (Majid, Hajari, Karimian, Hajiloo, 2013). Ma to nie tylko korzystny wpływ na już rozwinięte destynacje turystyczne, ale jest również pomocne w przypadku wsi rolniczych, w których tkwi potencjał rozwoju agroturystyki, ale nie podejmuje się działań o charakterze turystycznym, w związku z czym potrzeba odpowiednich strategii rozwoju (Bhatta, Ohe, Ciani, 2020).

W każdej analizie SWOT prezentowane są mocne i słabe strony oraz szanse i zagrożenia. Ogólnie rzecz ujmując, można ją podzielić na dwie części - pierwsza to analiza SW, którą przeprowadza się głównie w celu zbadania warunków wewnętrznych, druga zaś to analiza OT, którą wykorzystuje się przede wszystkim do określenia warunków zewnętrznych (Zhang, 2012). Dzięki tej metodzie można nie tylko zidentyfikować sprzyjające i korzystne czynniki, które należy promować na agroturystycznych terenach Jawy, opierając się na rolniczym LED, ale także uniknąć szkodliwych uwarunkowań. Pozwala ona ponadto na dostrzeżenie potencjalnych problemów, a także znalezienie ich rozwiązań oraz doprecyzowanie kierunków przyszłego rozwoju.

\section{Metoda BAdAWCZA}

W zaprezentowanym w niniejszym artykule badaniu zastosowano ilościowe i jakościowe podejście opisowe. Celem opracowania jest zrozumienie współczesnych zjawisk społecznych i socjologicznych, łączących się z różnorodnymi kwestiami z zakresu turystyki odnoszącymi się do obszaru Jawy. Autorzy zastosowali takie techniki zbierania danych, jak: ankiety, wywiady, obserwacje oraz dokumentacja.

Dane wykorzystane w niniejszym opracowaniu, pozyskane w latach 2019-2020, dotyczą zarówno zewnętrznych, jak i wewnętrznych czynników, które mogą wpływać na gospodarkę danej społeczności na terenach agroturystycznych. Respondenci biorący udział w badaniu to: członkowie społeczności, naukowcy praktycy oraz reprezentanci odpowiednich agencji rządowych. W tym przypadku potencjalni ankietowani to mieszkańcy oraz pracownicy agencji rządowych mających swoją siedzibę w pobliżu podmiotów związanych z agroturystyką. Pozyskane informacje zostały przetworzone i poddane analizie przy użyciu matrycy 
SWOT w celu opracowania strategii. Analizę danych można podzielić na następujące etapy:

1. Macierz oceny czynników wewnętrznych (IFE Matrix)

Macierz stworzono w celu ujawnienia mocnych i słabych stron przedsiębiorstwa (czynników wewnętrznych). W przypadku każdego czynnika wewnętrznego wykorzystano skalę ocen od 1 do 4, gdzie 1 oznacza znaczącą słabość, 2 - niewielką słabość, 3 - niewielką mocną stronę, a 4 - bardzo mocną stronę. Wartość oceny opiera się na wewnętrznej organizacji firmy oraz charakterystyce branży.

2. Macierz oceny czynników zewnętrznych (EFE Matrix)

Tę macierz wykorzystano w celu ujawnienie szans i zagrożeń danej firmy (czynników zewnętrznych). Każdemu czynnikowi zewnętrznemu przyznano ocenę w skali od 1 do 4, określająca, jak skuteczna jest obecna strategia przedsiębiorstwa $\mathrm{w}$ reagowaniu na ten czynnik. Dzięki temu dokonano oceny, opierając się na wewnętrznej organizacji firmy oraz charakterystyce branży.

3. Macierz oceny czynników wewnętrznych i zewnętrznych (IE Matrix)

Macierz IE (czynników wewnętrznych i zewnętrznych) to rozmieszczenie poszczególnych działów danej organizacji w dziewięciu komórkach. Działy, które znajdują się w komórce I, II lub IV, można określić jako rozwijające się. Intensywne strategie (penetracja rynku, rozwój rynku i produktu) lub integracja (odwrotna, przednia oraz horyzontalna) byłyby dla nich najbardziej odpowiednie. Działami znajdującymi się w komórce III, V lub VII można kierować, wykorzystując strategie ochronne i obronne; dwiema najczęściej stosowanymi z nich są penetracja rynku i rozwój produktu. Działy, które znajdują się w komórce VI, VIII lub IX, są uznawane za „pozyskujące” bądź „zbywające”.

4. Macierz SWOT

Macierz SWOT stanowi ważne narzędzie zestawiania danych, które pomaga przedsiębiorstwom w rozwijaniu czterech typów strategii, tj.: agresywnej (SO, maxi-maxi), konkurencyjnej (WO, mini-maxi), konserwatywnej (ST, maxi-mini) oraz defensywnej (WT, mini-mini). Poszczególne kroki w tworzeniu macierzy SWOT danego przedsiębiorstwa służą do tego, by wymienić następujące czynniki:

- kluczowe zewnętrzne szanse,

- główne zewnętrzne zagrożenia,

- podstawowe wewnętrzne mocne strony,

- podstawowe wewnętrzne słabe strony, oraz skorelować:

- mocne strony z zewnętrznymi szansami i wkalkulować wynik w strategię SO,

- słabe strony z zewnętrznymi szansami i wkalkulować wynik w strategię WO,
- mocne strony z zewnętrznymi zagrożeniami i wkalkulować wynik w strategię ST,

- słabe strony z zewnętrznymi zagrożeniami i wkalkulować wynik w strategię WT.

\section{WYNIKI}

\subsection{MACIERZ IFE}

Macierz IFE została przygotowana na podstawie wywiadów przeprowadzonych z kilkoma odpowiednimi agencjami rządowymi, naukowcami praktykami oraz mieszkańcami obszaru objętego badaniem. Nadawanie wagi przeprowadzono poprzez porównanie wszystkich wewnętrznych czynników agroturystyki w celu ustalenia priorytetów. Ponadto dokonano oceny poprzez przyjrzenie się rzeczywistym warunkom potencjału agroturystycznego w celu znalezienia głównych mocnych i słabych stron w rozwoju agroturystyki.

Rozwój turystyki ma mocne i słabe strony, które plasują się powyżej średniego wyniku 2,50. Jak widać w tabeli 1, jego główną siłą jest wysoce strategiczne położenie geograficzne z wynikiem 0,533.

Tabela 1. Macierz IFE

\begin{tabular}{|c|c|c|c|c|}
\hline Lp. & Czynniki wewnętrzne & Wartość & Ocena & Wynik \\
\hline \multicolumn{5}{|c|}{ Mocne strony } \\
\hline 1 & $\begin{array}{c}\text { Wysoce strategiczne } \\
\text { położenie geograficzne }\end{array}$ & 0,133 & 4 & 0,533 \\
\hline 2 & Odpowiednia siła robocza & 0,087 & 4 & 0,346 \\
\hline 3 & Wiek & 0,095 & 3 & 0,286 \\
\hline 4 & Poziom wykształcenia & 0,080 & 3 & 0,240 \\
\hline 5 & Wytrwałośćlmotywacja & 0,115 & 4 & 0,462 \\
\hline 6 & $\begin{array}{c}\text { Szeroko pojęte aspekty } \\
\text { marketingowe }\end{array}$ & 0,124 & 4 & 0,497 \\
\hline 7 & $\begin{array}{c}\text { Słabe strony } \\
\text { systemu informatycznego } \\
\text { w sektorze usług } \\
\text { publicznych }\end{array}$ & 0,061 & 2 & 0,122 \\
\hline 8 & $\begin{array}{c}\text { Źle ukierunkowane } \\
\text { wsparcie rządowe }\end{array}$ & 0,064 & 2 & 0,129 \\
\hline 9 & $\begin{array}{c}\text { Brak lokalnej } \\
\text { absorpcji pracy }\end{array}$ & 0,051 & 2 & 0,102 \\
\hline 10 & $\begin{array}{c}\text { Brak działań związanych } \\
\text { z planowaniem } \\
\text { i rozwojem biznesu } \\
\text { o potencjalnej } \\
\text { wartości gospodarczej }\end{array}$ & 0,132 & 1 & 0,132 \\
\hline 11 & \begin{tabular}{c} 
Złe zarządzanie odpadami \\
\hline 50,056
\end{tabular} & 2,000 & - & 2,962 \\
\hline
\end{tabular}

Źródło: opracowanie własne. 


\subsection{MATRYCA EFE}

Matryca EFE została przygotowana na podstawie wywiadów przeprowadzonych z kilkoma właściwymi agencjami rządowymi, naukowcami praktykami oraz mieszkańcami obszaru objętego badaniem. Nadawanie wagi odbywa się poprzez porównanie wszystkich czynników zewnętrznych w celu ustalenia priorytetów. Oceny dokonano, przewidując potencjalną reakcję branży agroturystycznej na szanse i zagrożenia, zarówno istniejące obecnie, jak i te, które pojawią się w przyszłości.

Z tabeli 2 wynika, że główną szansą na rozwój turystyki jest jej perspektywy rozwoju z wynikiem 0,836. Z kolei największym zagrożeniem jest niskie zainteresowanie społeczne rozwojem biznesu, które uzyskało wynik 0,206. Miejscowe stowarzyszenia, w tym stowarzyszenia rolników będących interesariuszami w agroturystyce, zajmują ważną pozycję w procesie planowania obywatelskiego, ponieważ mogą zapewnić odpowiednie wsparcie dla wielu różnych grup interesu (Wanner, Pröbstl-Haider, Feilhammer, 2021). Łączny wynik w odniesieniu do wszystkich czynników zewnętrznych wynosi 2,853. W przypadku radzenia sobie z szansami i zagrożeniami można to ocenić pozytywnie, ponieważ wynik przewyższył średnią normę kształtującą się na poziomie 2,50 .

Tabela 2. Macierz EFE

\begin{tabular}{|c|c|c|c|c|}
\hline Lp. & Czynniki zewnętrzne & Wartość & Ocena & Wynik \\
\hline \multicolumn{5}{|c|}{ Szanse } \\
\hline 1 & $\begin{array}{c}\text { Perspektywy rozwoju } \\
\text { agroturystyki }\end{array}$ & 0,209 & 4 & 0,836 \\
\hline 2 & $\begin{array}{c}\text { Zachowanie zasobów } \\
\text { naturalnych }\end{array}$ & 0,101 & 4 & 0,404 \\
\hline 3 & $\begin{array}{l}\text { Bogactwo produktów } \\
\text { wysokiej jakości }\end{array}$ & 0,094 & 3 & 0,282 \\
\hline 4 & $\begin{array}{l}\text { Duże możliwości wejścia } \\
\text { na rynek }\end{array}$ & 0,129 & 4 & 0,516 \\
\hline 5 & $\begin{array}{c}\text { Tworzenie stowarzyszeń } \\
\text { rolniczych }\end{array}$ & 0,086 & 3 & 0,259 \\
\hline \multicolumn{5}{|c|}{ Zagrożenia } \\
\hline 6 & $\begin{array}{c}\text { Małe zainteresowanie } \\
\text { społeczne rozwojem } \\
\text { biznesu }\end{array}$ & 0,206 & 1 & 0,206 \\
\hline 7 & $\begin{array}{l}\text { Stygmatyzacja społeczna } \\
\text { związana ze znaczeniem } \\
\text { wykształcenia }\end{array}$ & 0,054 & 2 & 0,109 \\
\hline 8 & $\begin{array}{l}\text { Duży odsetek } \\
\text { bezrobotnych w wieku } \\
\text { produkcyjnym }\end{array}$ & 0,059 & 2 & 0,118 \\
\hline 9 & Złe zarządzanie odpadami & 0,061 & 2 & 0,123 \\
\hline & & 1,000 & - & 2,853 \\
\hline
\end{tabular}

Źródło: opracowanie własne.
Wygląd tabeli 1 i 2 może determinować kształt macierzy kluczowych strategii lokalnego rozwoju gospodarczego w Jember Regency opartego na agrobiznesie. W tym przypadku chodzi o rozwój turystyki w jawajskich kabupatenach dzięki kwadrantowi analizy SWOT. Wartość IFE $(1,48)$ została przedstawiona na osi x, zaś wartość EFE $(1,43)$ na osi y (rysunek 1$)$. Jak widać na wykresie, rozwój agroturystyki plasuje się w kwadrancie (ćwiartce) 1, co oznacza, że charakteryzuje się wartościowymi mocnymi stronami i szansami.

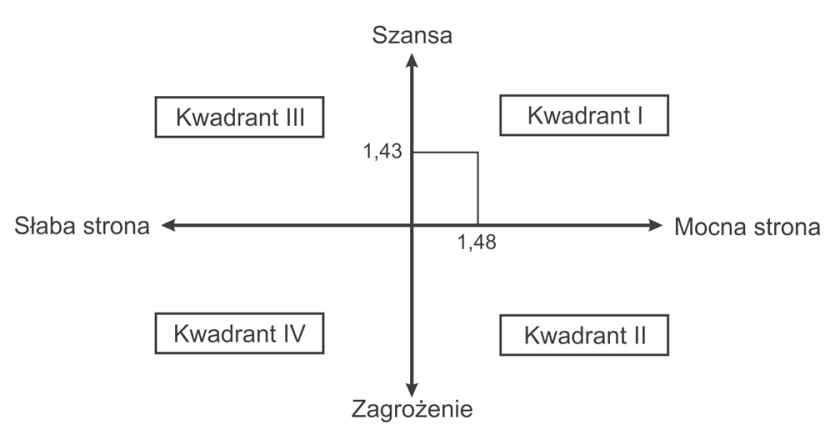

Rysunek 1. Macierz SWOT

Źródło: opracowanie własne

\subsection{MACIERZ IE}

Całkowity wynik ważony macierzy IFE wynosi 2,962, a w przypadku macierzy EFE - 2,853. Wyniki te zostały naniesione na macierz IE, na której oś x stanowi odwzorowanie całkowitej wartości matrycy IFE, oś y zaś - całkowitej wartości matrycy EFE. W ten sposób otrzymano matrycę IE (rysunek 2).

Na rysunku 2 widać, że rozwój agroturystyki plasuje się w komórce V. Uwzględnionymi w niej działami można odpowiednio kierować, stosując strategię utrzymania.

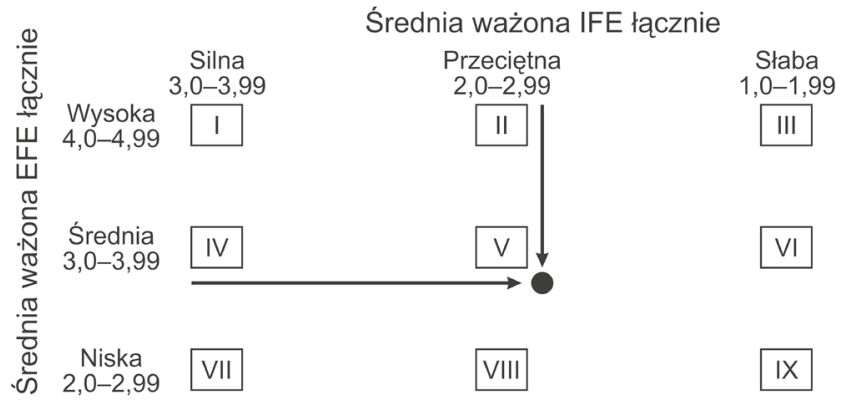

Rysunek 2. Matryca IE

Źródło: opracowanie własne

\subsection{MACIERZ SWOT}

Syntetyczne zestawienie wyników dotychczasowych analiz prezentuje macierz SWOT (tabela 3). Ułatwia ona wybór jednej z czterech możliwych strategii działania. 
Tabela 3. Macierz wyników analizy SWOT

\begin{tabular}{|c|c|c|c|}
\hline & \multicolumn{2}{|c|}{ Czynniki zewnętrzne } \\
\hline & & Mocne strony (S) & Słabe strony $(\mathrm{W})$ \\
\hline & & $\begin{array}{l}\text { - Wysoce strategiczne położenie geograficzne } \\
\text { - Odpowiednia siła robocza } \\
\text { - Wiek } \\
\text { - Poziom wykształcenia } \\
\text { - Wytrwałość/motywacja } \\
\text { - Szeroko pojęte aspekty marketingowe }\end{array}$ & $\begin{array}{l}\text { - Brak zadowalającego systemu } \\
\text { informatycznego w sektorze usług } \\
\text { publicznych } \\
\text {-Źle ukierunkowane wsparcie rządowe } \\
\text { - Brak lokalnej absorpcji pracy } \\
\text { - Brak działań związanych z planowaniem } \\
\text { i rozwojem biznesu o potencjalnej wartości } \\
\text { gospodarczej }\end{array}$ \\
\hline \multirow{4}{*}{ 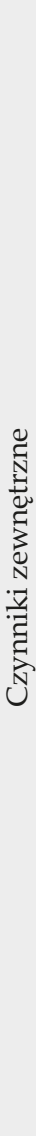 } & Szanse (O) & Strategie SO & Strategie WO \\
\hline & $\begin{array}{l}\text { - Perspektywy rozwoju } \\
\text { agroturystyki } \\
\text {-Zachowanie zasobów } \\
\text { naturalnych } \\
\text { - Bogactwo produktów } \\
\text { wysokiej jakości } \\
\text { - Duże możliwości wejścia } \\
\text { na rynek } \\
\text { - Tworzenie stowarzyszeń } \\
\text { rolniczych }\end{array}$ & $\begin{array}{l}\text { - Zapewnienie atrakcyjnych pakietów } \\
\text { turystycznych (S1, S2, S6 } \\
\text { oraz O1, O2, O4) } \\
\text { - Współpraca z mieszkańcami w celu } \\
\text { zapewnienia bazy noclegowej, by możliwe } \\
\text { było przyjmowanie większej liczy turystów } \\
\text { i wydłużenie czasu ich pobytu (S2, S5, S6 } \\
\text { oraz O3, O5) } \\
\text { - Tworzenie innowacji ukierunkowanych na } \\
\text { rozwój na podstawie przeprowadzonych } \\
\text { badań, umiejętności i doświadczenia, } \\
\text { w celu zwiększenia atrakcyjności } \\
\text { agroturystyki (S4, S5, S6 oraz O1, O4) }\end{array}$ & $\begin{array}{l}\text { - Usprawnienie technologii systemów } \\
\text { informatycznych oraz wykorzystanie } \\
\text { mediów społecznościowych w celu } \\
\text { promocji, by osiągnąć bardziej } \\
\text { wszechstronny rozwój agroturystyki } \\
\text { (W1 oraz O1, O4) } \\
\text { - Wspólna praca mająca na celu otwarcie } \\
\text { obszarów będących własnością } \\
\text { mieszkańców jako dodatkowych lokalizacji } \\
\text { turystycznych, które stanowiłyby odrębne } \\
\text { źródło dochodu dla stowarzyszeń rolników } \\
\text { (W2, W3 oraz O2, O5) } \\
\text {-Optymalizacja roli przewodników dzięki } \\
\text { mieszkańcom poprzez oferowanie usług } \\
\text { informacyjnych na temat turystyki } \\
\text { przyrodniczej oraz dostępnych produktów } \\
\text { wysokiej jakości (W1, W3 oraz O2, O3) }\end{array}$ \\
\hline & Zagrożenia (T) & Strategie ST & Strategie WT \\
\hline & $\begin{array}{l}\text { - Małe zainteresowanie } \\
\text { społeczne rozwojem } \\
\text { biznesu } \\
\text { - Stygmatyzacja społeczna } \\
\text { związana ze znaczeniem } \\
\text { wykształcenia } \\
\text { - Duży odsetek } \\
\text { bezrobotnych w wieku } \\
\text { produkcyjnym } \\
\text { - Złe zarządzanie odpadami }\end{array}$ & $\begin{array}{l}\text {-Zapewnienie pozytywnej motywacji } \\
\text { w zakresie znaczenia i poziomu } \\
\text { wykształcenia, które może pomóc } \\
\text { przezwyciężyć problem bezrobocia } \\
\text { wśród osób w wieku produkcyjnym oraz } \\
\text { zwiększyć zainteresowanie rozwojem } \\
\text { biznesu dzięki dodatkowym spostrzeżeniom } \\
\text { (S3, S4, S5, S6 oraz T1, T2, T3) } \\
\text {-Zwiększanie umiejętności, dzięki którym } \\
\text { można by wykorzystać odpady mające } \\
\text { wartość ekonomiczną (S2, S3, S5 oraz T4) }\end{array}$ & $\begin{array}{l}\text { - Integracja rządu z lokalną społecznością } \\
\text { związana z planowaniem oraz rozwojem } \\
\text { działalności w celu maksymalizacji jakości } \\
\text { usług publicznych, wsparcia rządowego } \\
\text { oraz pomocy w absorpcji miejscowych } \\
\text { pracowników (W1, W2, W3, W4 oraz T1, } \\
\text { - } \mathbb{P} 3 \text { momoc społeczności w rozwiązywaniu } \\
\text { problemu zanieczyszczenia środowiska } \\
\text { poprzez przetwarzanie odpadów w towary } \\
\text { mające wartość ekonomiczną (W4, W5 } \\
\text { oraz T4) }\end{array}$ \\
\hline
\end{tabular}

Źródło: opracowanie własne.

\section{DYSKUSJA}

Na podstawie informacji z tabeli 1 można uznać, że główną wadą rozwoju agroturystyki jest brak planowania i rozwoju działalności o potencjalnej wartości ekonomicznej, który uzyskał wynik 0,132. Dzięki temu łączny wynik integracji dla czynników wewnętrznych kształtuje się na poziomie 2,962. Determinantami rozwoju agroturystyki są: warunki geograficzne, położenie oraz przestrzeń agroturystyczna (Konečný, 2014). Jak ukazano na rysunku 2, rozwojem agroturystyki można kierować z zastosowaniem takich strategii intensywnych, jak penetracja rynku czy rozwój rynku i produktu. Są to dwie najczęściej stosowane strategie. Przyciąganie klientów, którzy nie są jeszcze stałymi klientami, a jedynie okazjonalnymi użytkownikami, poprzez zwiększanie lojalności wobec marki może się okazać skuteczną strategią szybkiego wzrostu rynku (Murden, 2020).

Niniejsze opracowanie pokazuje, że wysoce strategiczne położenie geograficzne może stanowić kluczową siłę rozwoju agroturystyki. W innych badaniach za taką siłę uznawano przeprowadzanie krytycznej oceny firm oraz podejmowanie strategicznych kroków, które pomagają im w przezwyciężaniu większości problemów (Eshun, Tettey, 2014). Jak już wspomniano, mocne strony i szanse są pozytywnymi czynnikami rozwoju turystyki na wsi, z kolei słabe strony i zagrożenia to czynniki negatywne (Bhatta, Ohe, Ciani, 2020). Rozwój regionalnej i lokalnej agroturystyki sprawia, że mocne strony wzmacniają się jeszcze bardziej, ponieważ dzięki niemu rozumienie regionu staje się pełniejsze, a jego potrzeby - jeszcze lepiej widoczne (Košak, Lugomer, 2015). 
Największą szansą są przyszłe możliwości rozwoju agroturystyki, z kolei za główne zagrożenie należy uznać małe zainteresowanie opinii publicznej rozwojem działalności. Niniejsza analiza jest zbieżna z kilkoma badaniami, których wyniki sugeruja że w wielu społecznościach generowany dochód przynosi korzyści tylko niektórym mieszkańcom wsi. Taki scenariusz może się rozwinąć w kierunku niebezpiecznej apatii związanej z rozwojem agroturystyki (Eshun, Tettey, 2014). Dlatego też regionalni decydenci zazwyczaj skupiają się na efektywności środowiskowej, by złagodzić negatywne skutki rozwoju agroturystyki (m.in. poprzez modernizację instalacji energetycznych) (Belliggiano, Garcia, Labianca, Valverde, De Rubertis, 2020). Niemal wszystkie obszary cechujące się wybitnymi i dobrze zachowanymi walorami kulturowymi dążą obecnie do włączenia lokalnych kultur i tradycji w rozwój agroturystyki (Mardiany, Kusuma, Rayes, Hakim, 2021). Inną szansą jest zapewnienie dostępu do zasobów przyrodniczych turystom lubiącym naturę oraz środowisko wiejskie - agroturystyka pozwoli im wziąć udział w zajęciach związanych z rolnictwem (Tew, Barbieri, 2012). Na terenach wiejskich warunki są stosunkowo sprzyjające rozwojowi agroturystyki (Bhatta, Ohe, Ciani, 2020).

Ponadto agencje rządowe powiązane z turystyką muszą przyjąć postawę opiekuńczą wobec rozwoju agroturystyki, ponieważ potrzebna jest nowa struktura instytucjonalna, aby wykorzystać jej potencjał do zrównoważonego rozwoju (Eshun, Tettey, 2014). Rozwój agroturystyki ma pozytywny wpływ zarówno na turystów, jak i na członków lokalnej społeczności (Maneenetr, Naipinit, Tran, 2014), dzięki wkładowi tradycyjnej wiedzy, który przekłada się na wzrost konkurencyjności oraz zrównoważony rozwój (Khanal, Shrestha, 2019; Mardiany, Kusuma, Rayes, Hakim, 2021).

Na podstawie wyników analizy można wesprzeć wysiłki gospodarcze podejmowane $w$ celu rozwoju agroturystyki poprzez wdrażanie alternatywnych strategii. Owe strategie mogą wiązać się ze wzbogaceniem oferty turystycznej o interesujące pakiety wycieczkowe, współpracą $\mathrm{z}$ lokalnymi mieszkańcami $\mathrm{w}$ celu poszerzenia bazy noclegowej, aby można było zakwaterować większą liczbę turystów i wydłużyć pobyty, oraz tworzeniem innowacji ukierunkowanych na rozwój i opartych na badaniach, umiejętnościach oraz doświadczeniach, które zwiększą atrakcyjność agroturystyki. Problemy, którym należy stawić czoła, to: brak właściwego systemu informatycznego w sektorze usług publicznych, źle ukierunkowane wsparcie rządowe, brak lokalnej absorpcji pracy, brak planowania i rozwoju działalności o potencjalnej wartości gospodarczej. Równie ważne są: zapewnienie pozytywnej motywacji związanej ze znaczeniem i poziomem wykształcenia, dzięki któremu można by rozwiązać problem bezrobocia wśród osób w wieku produkcyjnym, zwiększanie zainteresowania rozwojem działalności oraz dodatkowe obserwacje na ten temat, podnoszenie umiejętności, dzięki którym odpady mogłyby być wykorzystywane $\mathrm{w}$ taki sposób, by przynosić zyski ekonomiczne. Istotne są również: integracja struktur rządowych i członków lokalnej społeczności w celu planowania i rozwoju działalności, co zmaksymalizowałoby korzyści płynące z sektora usług publicznych, wsparcie rządowe ukierunkowane na pomoc w zwiększaniu absorpcji miejscowych pracowników, a także - w przypadku społeczności - pomoc $\mathrm{w}$ radzeniu sobie z problemem zanieczyszczenia środowiska poprzez przetwarzanie odpadów w produkty mające wartość ekonomiczną.

\section{WNIOSKI}

Z zaprezentowanych badań wynika, że niezbędne jest zapewnienie integracji pomiędzy członkami danej społeczności, praktykami oraz instytucjami rządowymi $\mathrm{w}$ celu wspierania i budowania potencjału istniejących zasobów. Mogą one bowiem mieć znaczący wpływ na rozwój gospodarczy lokalnej agroturystyki.

Opisane w opracowaniu wyniki są wartościowe, ponieważ ukazuja że strategie rozwoju lokalnego mogą stworzyć danej społeczności szansę na odgrywanie aktywnej roli oraz przejęcie inicjatywy w wyznaczaniu oraz przetwarzaniu lokalnych zasobów, zarówno ludzkich, jak i naturalnych. Strategia ta może pobudzić regionalną gospodarkę, uwolnić społeczność od barier, które ograniczają jej działalność, oraz zagwarantować prawidłowe funkcjonowanie jedynego w swoim rodzaju środowiska.

\section{PRZYPIS}

${ }^{1}$ Kecamatan - jednostka podziału administracyjnego w Indonezji; o szczebel niższa niż kabupaten i kota.

\section{REFERENCES/BIBLIOGRAFIA}

Athapaththu, H.K.S.H. (2016). An overview of strategic management: An analysis of the concepts and the importance of strategic management. International Journal of Scientific and Research Publications, 6 (2), 124-127. http://www.ijsrp.org/ research-paper-0216/ijsrp-p5019.pdf

Belliggiano, A., Garcia, E.C., Labianca, M., Valverde, F.N., De Rubertis, S. (2020). The "eco-effectiveness" of agritourism dynamics in Italy and Spain: A tool for evaluating regional sustainability. Sustainability, 12 (17), 7080. https://doi.org/10.3390/ SU12177080

Bhatta, K., Ohe, Y., Ciani, A. (2020). Which human resources are important for turning agritourism potential into reality? SWOT analysis in Rural Nepal. Agriculture, 10 (6), 197. https:// doi.org/10.3390/agriculture10060197 
Djuwendah, E., Karyani, T., Wulandari, E. (2021). Potential development strategy for attraction and community-based agrotourism in Lebakmuncang Village. E3S Web of Conferences, 249, 01004. https://doi.org/10.1051/E3SCONF/202124901004

Eshun, G., Tettey, C. (2014). Agrotourism development in Ghana: A study of its prospects and challenges at adjeikrom cocoa tour facility. Bulletin of Geography. Socio-Economic Series, 25 (25), 81-99. https://doi.org/10.2478/BOG-2014-0031

Ferreira, M.P., dos Reis, N.R., Pinto, C.F. (2016). Three decades of strategic management research on M\&As: Citations, cocitations, and topics. Global Economics and Management Review, 21 (1-2), 13-24. https://doi.org/10.1016/j.gemrev.2015.12.002

Garofoli, G. (2020). Local economic development. In: A. Kobayashi, International encyclopedia of human geography (pp. 199-206). Kingston: Elsevier. https://doi.org/10.1016/ b978-0-08-102295-5.10102-7

Hakim, L., Widyorini, R., Nugroho, W.D., Prayitno, T.A. (2021). Radial variability of fibrovascular bundle properties of salacca (Salacca zalacca) fronds cultivated on Turi Agrotourism in Yogyakarta, Indonesia. Biodiversitas, 22 (8), 3594-3603. https:// doi.org/10.13057/biodiv/d220861

Khanal, S., Shrestha, M. (2019). Agro-tourism: Prospects, importance, destinations and challenges in Nepal. Archives of Agriculture and Environmental Science, 4 (4), 464-471. https:// doi.org/10.26832/24566632.2019.0404013

Konečný, O. (2014). Geographical perspectives on agritourism in the Czech Republic. Moravian Geographical Reports, 22 (1), 15-23. https://doi.org/10.2478/mgr-2014-0002

Košak, M., Lugomer, K. (2015). The role of agrotourism in tourist season extension in Littoral Croatia. Hrvatski Geografski Glasnik, 77 (2), 141-168. https://doi.org/10.21861/HGG.2015.77.02.07

Krasavac-Chroneos, B., Radosavljević, K., Bradić-Martinović, A. (2018). SWOT analysis of the rural tourism as a channel of marketing for agricultural products in Serbia. Ekonomika Poljoprivrede, 65 (4), 1573-1584. https://doi.org/10.5937/ekopolj1804573k

Lin, Y.-C., Hsing, M.Y., Wang, Y.-C. (2008). Research on business strategy and performance evaluation in collaborative design. International Journal of Electronic Business Management, 6 (2), 57-69.

Mahanani, R.S.,Wiyono, L.C., Hidayat, T., Sugiartono, E.,Pratiwi, B.Y. (2020). Conceptualization of agribusiness / agro-industry potential study in Kemuning Lor Village, Arjasa District, Jember Regency. Advances in Social Science, Education and Humanities Research, 514, 165-169. https://doi.org/10.2991/ assehr.k.210101.037

Majid, R.S., Hajari, B., Karimian, T., Hajiloo, M. (2013). Rural tourism development strategies using SWOT analysis: Case study. Life Science Journal, 10 (4s), 395-403.

Mandisvika, G. (2015). The role and importance of local economic development in urban development: A case of Harare. Journal of Advocacy, Research and Education, 4 (3), 198-209.

Maneenetr, T., Naipinit, A., Tran, T.H. (2014). Guidelines to promote local community participation in developing agrotourism: A case study of Ban Mor Village, Sam Sung District, Khon Kaen Province, Thailand. Asian Social Science, 10 (9), 178-186. https://doi.org/10.5539/ASS.V10N9P178

Mardiany, Kusuma, Z., Rayes, M.L., Hakim, L. (2021). Indigenous knowledge-based agrotourism in the Dayak Kenyah Community in Pampang Village, Samarida, East Kalimantan. Journal of Marine and Island Cultures, 9 (1), 117-129. https://doi. org/10.21463/JMIC.2020.09.1.07

Meyer, D.F. (2014). Local economic development (LED), challenges and solutions: The case of the Northern Free State Region, South Africa. Mediterranean Journal of Social Sciences, 5 (16), 624-634. https://doi.org/10.5901/mjss.2014.v5n16p624

Mooney, A. (2007). Core competence, distinctive competence, and competitive advantage: What is the difference? Journal of
Education for Business, 83 (2), 110-115. https://doi.org/10.3200/ JOEB.83.2.110-115

Murden, H. (2020). Chapter 7 - strategy and implementation - business growth. Retrieved from: https://quizlet.com/174160321/ chapter-7-strategy-and-implementation-business-growth-flash-cards/ (5.07.2021).

Mustika, A., Khrisna Aditya, M. (2018). SWOT analysis of rural tourism development: case study of Kampung Tajur, Purwakarta. Advances in Economics, Business and Management Research, 52, 19-28. https://doi.org/10.2991/ictgtd-18.2018.3

Noviar, H., Masbar, R., Aliasuddin, Syahnur, S., Zulham, T., Saputra, J. (2020). The agricultural commercialisation and its impact on economy management: An application of duality-neoclassic and stochastic frontier approach. Industrial Engineering and Management Systems, 19 (3), 510-519. https:// doi.org/10.7232/iems.2020.19.3.510

Nuryasman, M.N., Nuringsih, K., Cokki (2020). Shift-share analysis of tourism industry growth in kulon progo yogyakarta. Industrial Engineering and Management Systems, 19 (3), 610-621. https://doi.org/10.7232/iems.2020.19.3.610

Omalaja, M.A., Eruola, O.A. (2011). Strategic management theory: Concepts, analysis and critiques in relation to corporate competitive advantage from the resource-based philosophy. Economic Analysis, 44 (1-2), 59-77.

Pal, S. (2016). A Study on the marketing strategies of agritourism centers in India. Atithya: A Journal of Hospitality, 2 (2), 33-38.

Rangkuti, F. (1997). Riset Pemasaran. $1^{\text {st }}$ ed. Jakarta: Gramedia Pustaka Utama.

Saxena, G., Clark, G., Oliver, T., Ilbery, B. (2007). Conceptualizing integrated rural tourism. Tourism Geographies, 9 (4), 347-370. https://doi.org/10.1080/14616680701647527

Shah, C., Shah, S., Shah, G.L. (2020). Agritourism as a local economic development tool for rural hill regions. In: W. Hasan, R. Singh, R.A. Siddique, D. Mahto, J. Kumar, A. Kumar (eds), Extension strategies for doubling farmer income (pp. 19-33). $1^{\text {st }}$ ed. New Delhi: Biotech Books.

Simms, A., Freshwater, D., Ward, J. (2014). The Rural Economic Capacity Index (RECI): A benchmarking tool to support community-based economic development. Economic Development Quarterly, 28 (4),351-363.https://doi.org/10.1177/0891242413512672

Swinburn, G., Goga, S., Murphy, F. (2006). Local economic development: A primer developing and implementing local economic development strategies and action plans. Washington: The Local Bank.

Tew, C., Barbieri, C. (2012). The perceived benefits of agritourism: The provider's perspective. Tourism Management, 33 (1), 215-224. https://doi.org/10.1016/J.TOURMAN.2011.02.005

Vogt, L. (2013). The economic side of agrotourism: Business performance and competitive factors. Economia Agro-Alimentare, 15 (3), 77-102. https://doi.org/10.3280/ECAG2013-003006

Wanner, A., Pröbstl-Haider, U., Feilhammer, M. (2021). The future of Alpine pastures - agricultural or tourism development? Experiences from the German Alps. Journal of Outdoor Recreation and Tourism, 35, 100405. https://doi.org/10.1016/j. jort.2021.100405

Wheelen, T.L., Hunger, J.D. (2012). Strategic management and business policy toward global sustainability. $13^{\text {th }}$ ed. New Jersey: Pearson Education.

Wolf, C., Floyd, S.W. (2013). Strategic planning research: Toward a theory-driven agenda. Journal of Management, 43 (6), 17541788. https://doi.org/10.1177/0149206313478185

World Bank (2011). Local economic development. Washington: Urban Development Unit.

Zhang, X.M. (2012). Research on the development strategies of rural tourism in Suzhou based on SWOT analysis. Energy Procedia, 16 (PART B), 1295-1299. https://doi.org/10.1016/j. egypro.2012.01.207 